\title{
NeW Relationships ON THE EAST COAST: alliancing, labour Relations at Hibernia, the Sable Gas Joint Public Review
}

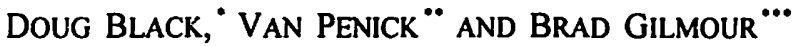

The authors examine the need for new and innovative approaches to oil and gas operations in light of the changing economic culture. In particular, the need for environmental assessments, alternative financing arrangements, complex tax rules and increased cross-border associations all require a more cooperative and flexible approach to completing a successful resource project.

The authors canvass three major developments: (I) the need for and the benefits and disadvantages of alliancing including contract formation, current alliances in the Canadian off-shore petroleum industry; (2) the impact of labour relations on the off-shore petroleum industry using the Hibernia project as an illustration; and (3) the joint public review panel on the Sable Gas project as an indicator of public participation.
Les auteurs examinent la nécessité de trouver des approches novatrices dans le secteur pétrolier et gazier en réponse à l'évolution de la culture économique. Il serait notamment impératif d'effectuer des évaluations environnementales et de trouver d'autres mécanismes de financement; la complexité des règles fiscales et l'augmentation des accords transfrontaliers exigeraient aussi une approche plus flexible et plus conviviale pour assurer le succès des initiatives relatives aux ressources naturelles.

Les auteurs étudient trois points importants: 1) la nécessité, les avantages et inconvénients des alliances, y compris la formation des contrats; les alliances actuelles dans l'industrie pétrolière canadienne en mer, 2) l'incidence des relations de travail dans le secteur de l'industrie pétrolière en mer d'après l'exemple du projet Hibernia, et 3) la Commission mixte d'evaluation pour l'examen du projet de la région de l'ile de Sable, en tant qu'indicateur de la participation publique.

\section{TABLE OF CONTENTS}

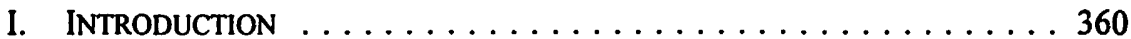

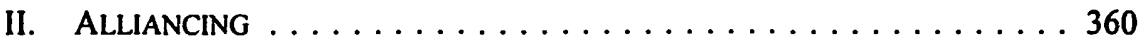

A. BACKGROUND to Strategic Alliances $\ldots \ldots \ldots \ldots \ldots 360$

B. TyPes of Strategic Alliances $\ldots \ldots \ldots \ldots \ldots \ldots \ldots 361$

C. Why Structure an Alliance? $\ldots \ldots \ldots \ldots \ldots \ldots \ldots 365$

D. BuIlding an Alliance $\ldots \ldots \ldots \ldots \ldots \ldots \ldots \ldots \ldots \ldots \ldots$

E. The Legal Aspects of Alliances $\ldots \ldots \ldots \ldots \ldots \ldots 373$

F. Alliances IN THE CANAdian OffShore Petroleum

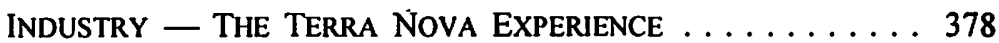

III. LABOUR RELATIONS AT HIBERNIA $\ldots \ldots \ldots \ldots \ldots \ldots \ldots \ldots 383$

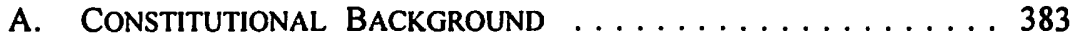

B. LABOUR RELATIONS DURING

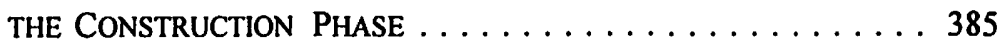

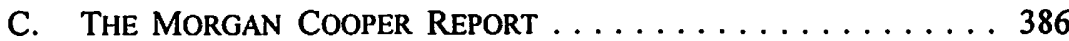

IV. The Sable Gas Projects Jont Public ReView Panel . . . . . 390

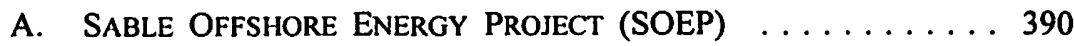

- Partner, Macleod Dixon.

-. Partner, McInnes Cooper \& Robertson.

... Associate, Bennett Jones Verchere. 


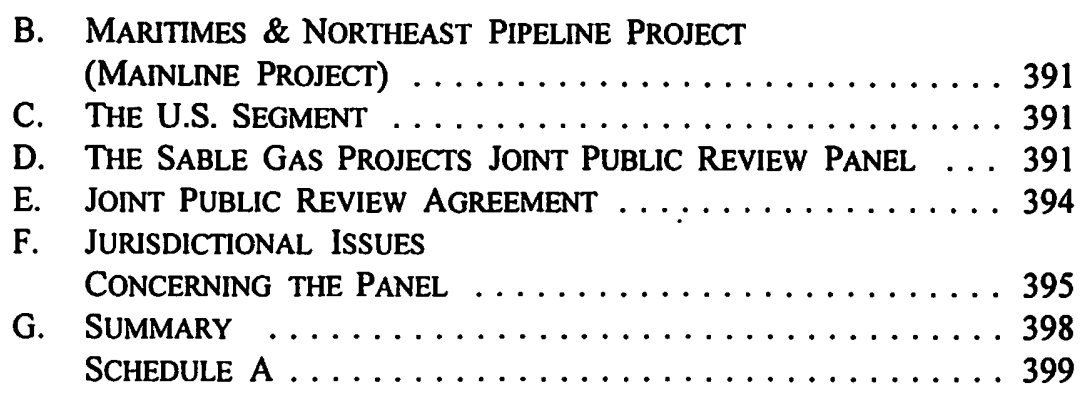

\section{INTRODUCTION}

Over the last twenty-five years, the business world and particularly the natural resources sector has become progressively more complex. Environmental assessment has been perhaps the number one contributor to this complexity but other factors have been the expanding array of financing options, the ever-widening circle of noncontractual liability, labyrinthine tax rules and, due to the dramatic growth of reliable high speed communications, increased opportunities for cross-border associations.

With this escalating pace of complexity and change, older and more rigid structures, jurisdictions and relationships are giving way to more fluid approaches to getting the job done. Some of these new approaches have developed on a more cooperative model which, to some extent, breaks down the more distinct and often more adversarial roles played by the parts which make up the whole of a resource project.

This article discusses three developments evident in current east coast oil and gas projects. These developments may be seen as responses to the ever more complicated environment of large projects:

- $\quad$ alliancing

- labour relations at Hibernia

- the Sable Gas Joint Public Review Panel.

\section{Alliancing}

\section{A. BaCkground to Strategic Alliances}

Joint ventures and other corporate alliances are not new business strategies. For example, as early as the nineteenth century the whaling and shipping industries relied heavily on joint ventures. During the mid- and late 1800 s, North American westward expansion was accomplished, in large part, by railway and mining alliances.'

R.P. Lynch, The Practical Guide to Joint Ventures and Corporate Alliances, 1st ed. (New York: John Wiley \& Sons, 1990) at 7. 
Throughout North America, the European community and Asia significant increases in the number of corporate alliances have occurred since the early $1980 \mathrm{s.}^{2}$ Strategic alliances are now commonplace in the petroleum, mining, chemical, high technology and real estate industries.

The two primary factors in the increasing numbers of alliances are thought to be the rise of technology and the globalization of markets. Expanding technological requirements have seen increasing research and development (R\&D) cooperation between organizations including businesses, universities and government institutions. Global integration of markets has been facilitated by great improvements in computer, communication and transportation technologies, and less restrictive trade policies. Information, goods and people now move more freely across international boundaries. National economies are becoming part of a single global economy. The European Community and the North American Free Trade Agreement provide examples of international arrangements designed to increase trade, cooperation and association.

The combined interdependence of technologies and world markets increases the need for cooperation between businesses and governments. Businesses are forced to consider new ways of competing as markets and technologies expand and change.

Other factors which have encouraged alliances include the "hybridization" of technologies to produce entirely new products, the need to bring products to the market faster, the sharing of risk associated with large capital expenditures, the sharing of management resources and skills, the tightening of venture capital markets, and economies of scale. ${ }^{3}$ In addition, strategic alliances are seen as attractive alternatives to mergers and acquisitions. ${ }^{4}$

Alliancing has proven to be a successful strategy in the offshore petroleum industry. For example, the successful development of the Andrew Field in the North Sea by British Petroleum (BP) is credited in large part to alliancing. In the Canadian off-shore petroleum industry, the design of the Terra Nova project was accomplished using an alliancing strategy. In addition, the Sable Offshore Energy Project will be developed by an alliance group. In general, the oil and gas industry on the east coast is seen to be moving toward collaborative relationships in offshore development. ${ }^{5}$

\section{B. Types of Strategic alliances}

There are several ways in which corporations may form strategic alliances. Many of these forms are difficult to distinguish since they share a great number of similarities. Alliances can be as simple and as independent as a contractual arrangement, or as

2 J.D. Lewis, Parınerships for Profit: Structuring and Managing Strategic Alliances, 1st ed. (New York: The Free Press, 1990) at 9.

Lynch, supra note I at 8-14.

4 B.H. Crombie, Joint Ventures and Strategic Alliances: Making Them Work (Toronto: Insight Press, 1995) at 143.

s M. Harrington, Q.C. et al., "Emerging Issues in East Coast Oil and Gas Development" (1997) 35 Alta. L. Rev. 269 at 299. 
complex and intertwined as a joint venture. In any case, a strategic alliance is the bringing together of two or more companies to help produce, promote and sell their products.

Strategic alliances are different from other growth-enhancing strategies in part because the partners maintain their independence. Strategic alliances are typically goalspecific and created to achieve medium- to long-term objectives subject to set time frames and termination dates. Once the objectives of the alliance have been achieved, it is typically disbanded.

The key features of strategic alliances have been described as follows:

In short, the major features of strategic alliances appear to be: the relative continuing independence of the parties in respect of those matters not covered by the alliance; a set (albeit longer-term) time frame; limited scope of the arrangement and greater flexibility of the parties compared to takeovers or acquisitions; and, reciprocity between parties, as seen in the sharing of objectives, information and key assets.

Joint ventures, although often considered to be strategic alliances, may be distinguished from other less complex strategic alliances as follows:

A joint venture is a cooperative business activity, formed by two or more separate organizations for strategic purposes, it creates an independent business entity and allocates ownership, operational responsibilities, and financial risks and rewards to each member, while preserving their separate identity/autonomy. ${ }^{?}$

Thus, the distinction between a joint venture and other types of strategic alliances is that the former results in a new, independent business entity. Regardless of the precise strategic arrangement, many of the strategic and operational considerations and principles are the same. Lynch describes the nature of alliances as follows:

Joint ventures and strategic alliances are often compared to "marriages" between businesses. This is sometimes a good analogy, but more often than not the analogy confuses the business relationships and creates unrealistic expectations of the partners and other observers. In reality, both joint ventures and strategic alliances are simply basic and natural forms of business cooperation. Some are short-term love affairs to create a new product, a new building, or a project, only to be intentionally dissolved once the objectives are achieved. Others are designed to take advantage of rapidly changing environments and then terminate, with the former partners reemerging in another alignment to take advantage of the next opportunity. Still others are long-term, permanent organizations that take on a life of their own.

For businesses, the joint venture and strategic alliance form a bridge to the future to gain important strategic advantage. Neither participant is permanently bound to what might otherwise be an

Director of Investigation and Research, Competition Act, Strategic Alliances under the "Competition Act" (Ottawa: Industry Canada, November 1995) at 3 [hereinafter Strategic Alliances]. 
unwielding [sic] merger, an ill-conceived acquisition, or an overly risky incursion into unchartered territory.

The nature of an alliance can be determined by considering its structure and its objects. An alliance may be structured in many different ways including contractual relations, partnerships and joint ventures. Common forms of strategic alliances include partnerships, non-controlling minority investments, buy-in joint ventures, joint venture mergers, lead-parent joint ventures and 50-50 joint ventures. More informal and less complex alliances may be formed based on past relationships and trust, or according to contractual arrangements.

Alliances may be formed for the purpose of achieving a host of different objectives. For example, two companies that produce complementary products might form an alliance for the purpose of providing enhanced product value. Other companies may choose to partner for the purpose of enhancing product image. A familiar example of an image-enhancing alliance is found in the computer industry where some computer manufacturers proudly display the "Intel Inside" logo.

Forming technology networks is also a potentially beneficial form of an alliance. A firm may form technology alliances with universities, other firms, and with governments. Such alliances reduce R\&D expenses and keep the firms within the alliance up to date on new technological advances.

"Spin-off" product partnerships are another common form of alliance. For example, two companies could jettison two non-core products or activities to an alliance and focus internal efforts on core strengths. The following example illustrates a successful spin-off alliance:

Dow Chemical has used alliances in this way to concentrate on its core businesses. The firm's Dowell oilfield services subsidiary, for example, needed a management style that could adjust to the highly cyclical oil business. Dow found it hard to manage this unit in all but the boom phase of the cycle. Moreover, other firms, including Schlumberger, for which oilfield services is a core business, were more adept at managing such activities.

Using this reasoning, Dow moved the unit into a joint venture with Schlumberger. Dow realized the gain from selling 50 percent of Dowell and continues to participate in a growth business. In fact, Schlumberger's management input has carried the enterprise well past what Dow could have done alone. Schlumberger gained a unit that complements its basic business, plus a partner with a strong technical background to help it maintain a leadership position. ${ }^{9}$

Forming alliances can have a significant impact on reducing entry barriers and increasing access to other markets. This is particularly true in the case of international business where forming an alliance with a local company brings instant historical 
perspective and positioning in a foreign market. Such an example is Air Canada's recently announced "Strategic Alliance" of four major air carriers around the globe.

Forming alliances may facilitate opportunities for smaller firms to compete on the same scale as industry leaders; what the individual entities cannot do on their own, they can achieve jointly. Contrary to conventional business thought, forming strategic alliances with competitors may also produce competitive advantage. On this point, Lewis provides the following reasons.

The strongest reason to work with a competitor is to face a common opponent:

- Major newspapers in Miami, Pittsburgh, San Francisco, and other cities compete for readers and advertisers and share facilities to lower their cost in the face of revenue losses to TV and other publications.

- Glass container makers compete with each other and sponsor joint research to improve their product in relation to cans.

- Apple Computer and Digital Equipment compete head-to-head in the office equipment market. Simultaneously, they have developed common standards to contend with IBM.

- Ford dealers in metropolitan areas sell against each other and support joint advertising to compete with other makes.

- Major pharmaceutical firms use each other's sales forces to build market share for their products ahead of others' competing products. ${ }^{10}$

In addition, much of the offshore exploration and development in the North Sea has been performed by alliances of major competitors such as Exxon and Shell.

Alliances may also be used to reinforce key partnerships. Reinforcing key partnerships may involve creating alliances with customers, suppliers, sub-contractors and distributors. The benefits of such alliances may include lower marketing and administrative costs, the creation of unique value to the benefit of the customer, greater market access and greater long-term strength.

Lewis describes a situation where a major distributor of drugs and health care products formed a network of value-adding alliances that linked manufacturers, distributors, retailers, consumers and insurance firms. The result was that independent drug stores served by the distributing firm could offer their customers better prices and service including a more targeted product mix, and faster insurance payments. " 
Network alliances are common in the petroleum industry. For example, Canadian Hunter Exploration Ltd. has been involved in several strategic alliances that have brought together members of partner companies with expertise in a variety of disciplines including geology, engineering, geophysics and marketing. ${ }^{12}$ As discussed in more detail below, Petro-Canada's approach for the design of the Terra Nova project was to create an alliance of companies with expertise in a full range of services necessary to create the best design.

\section{Why Structure an Alliance?}

Alliances are but one means of building corporate strength; others include building upon the company's own internal strengths, making acquisitions or entering into traditional "one-time" contracts. Which strategy is chosen will depend primarily on the specific objectives of the corporation and its need for control.

The "one-time" contract is the most common way corporations acquire their needed goods and services. The relationship between the two corporations involved is governed entirely by the contractual relationship. Under these types of relationships there is typically little need for extensive interaction between the parties.

Acquisitions become more beneficial in cases where two firms must operate under the same management in order to obtain long-term success. Acquisitions are more likely to be successful if the buyer and the target company are closely related since a common risk in acquisitions is a failure to effectively integrate the two separate entities.

One of the primary advantages of strategic alliances over acquisitions is that the partners can create any mix of resources that meet their separate and mutual objectives. That is, companies with different strengths can unite for a specific purpose to create a unique or enhanced outcome. In addition, alliances can be project-oriented and can be dissolved upon completion of the project. The only elements which must merge in an alliance are those which must come together to form a greater common good between the two entities. Alliances provide an opportunity for corporations to exploit the strengths of each member company and form a unit that is greater than the sum of its parts.

Alliances and joint ventures often prove to facilitate easier integration of two companies than do mergers or acquisitions. B.H. Crombie, Senior Vice President, Corporate Finance, for the Molson Companies Ltd., describes this point as follows:

Joint ventures force two or more parties to discuss the commercial logic of a combination, to put together a business plan, and to discuss people issues and cooperatively work on the execution. Joint ventures usually don't have a conqueror and a victim, they have two equals both working to create value. $^{13}$

13 Crombie, supra note 4 at 144. 
Companies that enter into an alliance hope to realize benefits that cannot be achieved individually. Partners in alliances are looking for a win-win opportunity that brings together the individual strengths of each of the separate entities to achieve a synergistic result. The incentive for creating an alliance is typically the possibility of obtaining a superior and more cost-effective result.

J.K. Gray, of Canadian Hunter Exploration Ltd., believes that the keys to success for the Canadian petroleum industry over the next decade will be: (1) adding of production and reserves at low unit cost; (2) constant attention to cost control; (3) operating profitability on the basis of conservative price forecasts; (4) maintenance of leading edge technology; and (5) maintenance of an aggressive and skilled exploration organization during a time of depressed energy prices. ${ }^{14}$ Gray believes that strategic alliances, both foreign and domestic, will be key survival strategies. He suggests that no single firm will possess the full range of necessary skills and predicts that strategic alliances which combine joint exploration and exploitation teams, for example, will become common.

Gray believes that one of the major incentives of forming strategic alliances will be the promise of considerable cost savings. He indicates that substantial savings in administrative costs and in avoiding duplication will result in greater efficiency and cost reduction.

Gray sees the main benefits of alliances as greater efficiency and improved productivity. Other advantages in the petroleum industry include enhanced funding, technology and research, exploration and production skills, administrative support, and marketing activities.

\section{Building an Alliance}

\section{BASIC Legal Structure for Alliances}

Lynch describes four basic options for structuring an alliance: (1) a joint venture corporation; (2) a partnership; (3) a written contract; or (4) a handshake. ${ }^{\text {is }}$ The ultimate choice of the legal structure will be dependent upon the objectives of the alliance, the risks and rewards of the alliance and the operating principles of the alliance.

\section{a. Joint Venture Corporation}

Forming a separate joint venture corporation is the most complex form of strategic alliance. Lynch describes several factors which may indicate that a joint venture corporation is the superior strategy:

$4 \quad$ Gray, supra note 12 at 6.

is Lynch, supra note 1 at 117. 
- when the joint venture is large or complex enough to require a separate organizational entity with its own internal management;

- if it is advisable to contribute cash directly to the joint venture and, in return for the cash, the joint venture partners receive stock in the new company;

- when the joint venture's goal is longterm. ${ }^{16}$

One of the primary advantages of forming a separate corporation is that the alliance corporation is managed independently. Such an arrangement alleviates the requirement for the two partners to be involved at the management decision level.

\section{b. Partnership}

The most widely used form of strategic alliance is the partnership. One of the likely reasons that a partnership is chosen most often is its high degree of flexibility. A partnership, in essence, is a legal structure that allocates investment, profits, losses and operational responsibilities, while at the same time maintaining the independence of the partners. Management may be accomplished by forming a committee to manage the needs of the partnership where the committee is composed of members of each partner. Lynch states the following concerning the partnership alliance:

The partnership form is most often selected when one or more of these conditions prevail:

- when the alliance is expected to last only three to five years (i.e., it is project-oriented);

- if a separate business entity is desirable for the alliance, but a separate organization for management of the venture is not currently required, but may be needed in the future;

- if high levels of commitment and interaction are necessary for short periods of time. ${ }^{17}$

\section{c. Contractual Relations}

Contractual relationships are often chosen for strategic alliances because they maintain an arm's length relationship between the partners. The contract outlines the essential elements of the alliance including division of risk and rewards, specific responsibilities and confidentiality. Contracts are typically used in cases where the alliance is created for a short term, where specific and detailed management of operations is not required, or where the two partners are entering into a relationship for the first time and an atmosphere of trust has not yet been created.

Contractual alliances differ from "one-time" contracts in that the partners typically make some attempt to align their long-term interests. As a result, information exchanges

16 Ibid.

$17 \quad$ Ibid. at 118. 
concerning technology, know-how and operations are typically greater under a contractual alliance than under a "one-time" contract.

\section{d. Handshake}

Handshake agreements are used in cases where a written agreement would otherwise be used but where there exists a strong element of trust. Alliances formed by handshakes typically arise in cases where the agreement is for a short period of time, where no separate management is required or where there is a need to work together for an interim period before final agreements are prepared. It is essential that a strong element of trust be developed between the partners before this strategy is employed.

Given the obvious risks and uncertainties associated with handshake agreements, they should be the exception rather than the rule.

Ultimately, the decision on what form of strategic alliance is chosen will be very much dependent upon the specific needs of the partners. Lynch suggests several factors which may be considered when choosing an appropriate legal structure for an alliance:

(1) Simplicity. Use the simplest structure capable of meeting the partners' needs. Do not form a corporation if a written contract will do.

(2) Number of Partners. If the number of partners is three or less, and the alliance will probably not last for more than three to five years, the partnership or written contract may be sufficient. As the lifespan of the venture increases and the number of parties increase, the corporate form may become superior.

(3) Expected Longevity. Alliances intended to last only a few years are probably better advised to use the written contract or partnership form, whereas long-term ventures are best served when they use the corporate form.

(4) Tax Considerations. If significant tax sheltering is desirable, particularly for technology development where large losses or R\&D investment tax credits are anticipated, a tax lawyer should be consulted for specific advice regarding the ways to maximize use of the tax shelter. A legal structure that maximizes tax sheltering may not be the best form to use to maximize other management efficiencies.

(5) Ease of Management. Alliances that do not require a high degree of integration of planning, decision-making and operational integration over the long haul can use the written contract or partnership form effectively. However, if a high level of integration is required, only those companies with good abilities or experience with joint venture management should consider the partnership forms; otherwise, the corporate form may be better because it forces stronger management. 
(6) Capital Investment. If significant investment is required, the partnership form may have far better tax effects than the corporation, but it may be easier to raise larger amounts of capital from the sale of stock in a corporation.

(7) Leadership, Management, Co-ordination and Support. These issues can make or break the alliance. Considerable attention must be given to them, regardless of the legal structure. The management systems should be clearly decided before the legal agreements are formally signed. ${ }^{18}$

\section{Designing a Strategic Alliance}

Structuring an alliance will require consideration of many issues including selecting the "right" partner, setting mutual objectives, negotiating the alliance, legal matters, organizational frameworks and distribution of risks and rewards.

\section{a. Selecting the Right Partner}

The first step in planning an alliance involves selecting the right partner. This is perhaps the most critical stage of forming an alliance since the success of an alliance is based in large part on trust and the ability to cooperate. Lynch describes the necessity of trust as follows:

Without high levels of trust, there will be no chemistry, and without chemistry the venture is doomed. Alliances are usually risky ventures. Difficulties are bound to arise, and if communications are not excellent, good problem-solving will not occur to address the difficulties. Inevitably, in an environment of low trust, there will be blame-setting rather than problem-setting; at which point the venture is on its way to oblivion or divorce. ${ }^{19}$

Simply getting to know a prospective partner is essential before formal agreements are entered into. The parties should, at first, undertake discussions informally to define mutual objectives and to gain familiarity.

During preliminary negotiations, both parties should be evaluating the "chemistry" between the parties and assessing whether or not there will be a strong fit between the two separate entities. Preliminary contacts should not be solely for negotiating the structure of the alliance but should be used to gain valuable information about the likelihood of success of the alliance. Characteristics such as ability to achieve results, promptness of replies, energy and momentum, commitment, responsiveness, problemsolving, communications, and willingness to work as a team should be critiqued throughout the initial negotiation stages. 


\section{b. Due Diligence}

Traditional elements of corporate due diligence are also applicable to alliancing. Areas of review during the due diligence process may include financial statements, court files, industry reputation, quality of top managers, past strategic alliances and core organizational values or culture.

\section{c. Setting Mutual Objectives}

Companies should explore the objectives of the alliance and the benefits that each partner hopes to achieve. Each of the companies must try to determine at the outset its respective objectives and what each expects to realize and gain from the alliance. It is essential that the objectives of both parties be fully explored. The goal should be to ensure that both or all companies making up the alliance will achieve benefits from the alliance that they could not have otherwise achieved independently.

Both positive and negative expectations should be stated up front. Without clearly defining the expectations of both parties, the relationship between the parties may be undermined by disappointment. Clearly stated expectations can be used to measure progress toward mutual objectives.

\section{d. Negotiating the Alliance}

Despite the added trust and cooperation inherent in strategic alliances, partners should carefully consider who will form part of the alliance negotiating team. Typically, the team will be composed primarily of members of senior management. The focus of senior management will be on the financial aspects of the joint project. Equally important is operational fit. Thus, operational managers should be part of the negotiating team. Operational managers can focus on technology, human resources and scheduling. It is also important to include operational managers since they will be involved in implementing the alliance.

Lynch suggests several factors to keep in mind when negotiating the initial deal: ${ }^{20}$

- Reinforce critical appraisal and foster an atmosphere that approves of skepticism and critical discussion.

- Leaders should refrain from pushing their own view; instead, they should encourage healthy debate until a decision must be made.

- Avoid having a single, insulated group make the decision.

- Create opportunities for experts in the middle levels of the organization to give their critical reviews. ${ }^{21}$ 
The tone of negotiations in the alliance sets an important precedent for the ultimate success of the alliance. Lynch states the following on this point:

People who are good at negotiating in adversarial situations may not necessarily be good at negotiating a joint venture. Negotiating a joint venture is not like buying a house or a car. It is more like arranging a marriage. It is far more important to determine if 'one plus one equals three,' than to 'squeeze the last concessions' out of an opponent. Your objective is to create a 'win/win,' not a 'win/ose,' condition. Remember, you will have to rely upon your partners when problems occur. Make sure your partner is with you, and not anxious to regain the advantages they perceive were lost in original negotiations. $^{22}$

\section{e. Confidentiality}

It is essential to ensure that proprietary information is kept confidential until mutual confidentiality agreements are entered into. The rigor with which this rule is followed will depend on trust and past relationships. Protecting proprietary information is critical for smaller companies whose entire existence and future is based upon their unique technology and knowledge.

\section{f. Power and Control Issues}

One of the fundamental themes in alliancing is cooperation. Thus, the sharing of power is an intrinsic component of strategic alliances. Alliances are not based on domination and control, and should be designed so that power is shared. Lynch describes several key considerations concerning power and control of an alliance as follows:

One of the best methods of dealing with power and control is not to talk about it in theory, but rather to discuss specific operational conditions in detail, such as:

- How are decisions made to select design specifications?

- Who has responsibility for details such as packaging? Press releases?

- What authority does the project manager have to allocate funding?

- Who has veto power over what decisions?

- What personnel will be transferred to the alliance? ${ }^{23}$

Answers to questions of this type set the framework for the non-binding statement of intent. 


\section{g. Role of Lawyers}

The primary role of lawyers is to protect their clients from risks. It is difficult, if not impossible, for lawyers to depart from this paradigm. They are taught from their first days in law school to champion the interests of clients, to the exclusion of all others, save those interests which offend the law. This function of the lawyer may not be conducive to the negotiation of an alliance. Lynch describes the lawyer's role in structuring alliances as follows:

True, overly zealous or conservative lawyers may occasionally protect their clients right out of an alliance, but more often than not, the probing analysis of a good legal counsel has saved an idealist from a poorly conceived venture.

There is little need for attorneys to be present during the earliest stages of negotiation, but they should be consulted to draft confidentiality and non-compete agreements, to protect against securities and exchange violations, and ask hard questions about commitments and contingencies so the business participants can prepare solutions.

Perceptive lawyers will also have a natural tendency to find the weak points in a deal and focus $\mathbf{8 0}$ percent of their efforts on these issues. In an attempt to rectify fuzzy points or areas of potential disagreement, lawyers may negotiate terminology that tends to drive a wedge between potential partners and jeopardize their future working relationship. Managers should carefully review and weigh this legal advice privately before introducing such rough edges into the negotiations.

A business should avoid bringing an attorney to the bargaining table as its negotiating agent; this only encourages the other side to do the same. Then the negotiations may turn into an adversarial process, with each lawyer protecting his or her client right out of the deal. ${ }^{24}$

Lawyers have valuable contributions to make in forming alliances, however, the involvement should be largely behind the scenes. Lynch cites the words of a U.S. attorney on the role of lawyers in joint venturing:

I don'tbelieve an attorney should make business deals - generally we just aren'tgood at it. We should be advisers, we should be involved from the beginning, but not necessarily at the bargaining table. But if a business deal goes too far down the road without an attorney's input, it could strain the relationship between client and counsel. The client will think the attorney is not creative and the attomey will feel he is giving awkward advice. ${ }^{25}$

While lawyers should play a background role, this does not mean that they should play an insignificant role. Lawyers are vital in finalizing the ultimate agreement to ensure that the mutual objectives of the parties have been fully addressed. 


\title{
E. The Legal Aspects of Alliances
}

Many alliances involve formal agreements, however, as discussed above, a contract is not always necessary. The lower the risk and the greater the trust, the less likely that a formal contractual relationship will be required by parties. Alliances that are structured by contracts may be seen to have restricted flexibility as compared to informal relations.

Lynch states the following concerning the length and detail of agreements for alliances and joint ventures:

\begin{abstract}
When properly constructed, a business alliance should be worked out clearly in terms of the strategic, management, financial, and operational objectives well in advance of the final legal agreements. This is why most agreements are only ten to thirty pages in length, and many smaller ventures are supported by even fewer pages. When compared to other legal arrangements, joint ventures and strategic alliances are a relatively simple endeavor. (Compare this to an equity investment or project financing document, often over 250 pages long! $)^{26}$
\end{abstract}

\section{Creating the Legal agreement}

Lynch outlines a typical sequence in creating a written alliance agreement as follows: (1) a statement of intent, (2) non-competition and confidentiality agreements, and (3) the legally binding written contract. ${ }^{27}$

\section{THE STATEMENT OF INTENT}

One of the most critical stages in formulating an alliance is the preparation and drafting of a non-binding statement of intent. The primary purpose of the statement of intent is to take the negotiations from issue and objective formulation to clearly defined terms and conditions. The statement of intent should be formalized prior to developing binding agreements and should be negotiated by the selected negotiating team, without the direct involvement of lawyers. Ultimately, the lawyer will be responsible for translating the statement of intent into a binding and formalized agreement.

Lynch suggests that eight critical issues be addressed in the statement of intent: ${ }^{28}$

(1) spirit and purpose of the agreement which briefly outlines the reasons and objectives for forming the alliance;

(2) realm of activity, which should describe which products, services, buildings, or other specific projects will be included and excluded from the partnership; 
(3) key objectives and responsibilities which clearly state the objectives and schedules to be achieved by the alliance and which clearly sets out individual responsibilities for management;

(4) method for decision-making, describing who will have the authority to make specified types of decisions;

(5) resource commitments describing the types of resources that will be provided by each of the participants, including cash, equity, loan guarantees, licenses, knowledge, contacts, production facilities, inventory, raw materials, engineering drawings, management staff, time commitments, etc.;

(6) assumption of risks and division of rewards, which covers how risks and rewards will be shared between the parties;

(7) rights and exclusions, for example who has the right to the products and intellectual property of the venture, etc.; and

(8) anticipated structure, describing the intended structure of the venture (i.e. written contract, corporation or partnership).

Lynch suggests that at the bottom of the statement of intent, a paragraph should be included as follows:

This nonbinding letter contains preliminary intentions of the parties to form an alliance based on conditions stated above. Upon review by our respective legal counsel and upon mutual agreement, revisions may be proposed to be included later in a formal, binding legal agreement, which, contingent upon our signing, will legally bind the parties. For the next 60 days, the parties agree to adhere to the principals of this statement of intent until superseded by the formal legal agreement, the extension or modification of this agreement, or the decision to abandon the alliance prior to entering into a formal legal agreement. ${ }^{29}$

Each of the partners should sign the statement of intent to signify commitment. While not legally binding, the statement of intent is the product of a significant amount of negotiation, strategizing, relationship evaluation and building, and forms the basis for more formalized agreements.

\section{CONFIDENTIALITY AGREEMENTS}

Confidentiality agreements are essential where the partners will be sharing valuable technology or other proprietary information. Confidentiality agreements help to facilitate the development of trust by creating a comfort level for the partners. Clearly defining what information must be kept confidential allows the parties to negotiate more openly. 
Lynch suggests six basic issues that should be addressed in a confidentiality agreement: ${ }^{30}$

(1) Defining the confidential information. The agreement must describe the confidential information in sufficient detail to make it perfectly clear what is within the bounds of the agreement and what is not. The definition must be both encompassing and specific in order to make the agreement enforceable.

(2) Control. Specific provisions should be included to establish who can know the confidential information and where copies will be maintained. By doing so, the parties are forced to focus on how each company will maintain confidentiality within its organization. It is frequently desirable to have an attachment to the agreement setting forth the form of an abbreviated confidentiality agreement to be signed by persons having access to the information. By doing so, a further degree of control is imposed.

(3) Derivative works. For technology-oriented companies, it is often possible to derive other inventions from the source of technology. The ownership of such inventions should be dealt with in the agreement. If feasible, include a provision describing notice and transfer provisions.

(4) Fall-back position. In case an alliance is never established, the confidentiality agreement may be the only agreement between the parties. It should contain an understanding regarding products derived from the technology and other sensitive matters, thereby helping to avoid litigation if the remaining negotiations do not go well.

(5) Survival. Regardless of any further negotiations for an alliance, the confidentiality agreement should survive for a reasonable time period for the provisions to remain in effect (i.e. for as long as the confidential information is not publicly known or for a minimum number of years).

(6) Relief. Because it is difficult to establish damages that might result from a breach of the agreement, it is useful to spell out whether one of the parties can request an injunction and the amount of damages the parties agree are appropriate.

\section{NON-COMPETITION AGREEMENTS}

The parties to an alliance may also choose to agree not to enter into markets or produce products that compete with any of the partners or the alliance. Such agreements should be drafted in light of competition laws. ${ }^{31}$

3o Ibid. at 151.

3 For an overview of how strategic alliances will be addressed under Canadian competition law see Strategic Alliances, supra note 6. 
Lynch suggests that non-competition agreements should cover the following two points: (1) duration - define how long non-competition will be in effect; and (2) scope - clearly define the particular technology, products or services which are subject to the agreement.

\section{THE Formal LEGAL AGREEMENT}

The legal agreement should follow the basic structure of the statement of intent. Lawyers should be involved in drafting and reviewing the legal agreement to ensure that the intentions of the parties have been captured and are clearly defined.

The provisions that are included in the ultimate agreement will obviously depend on the specific objectives and structure of the alliance. As discussed above, there is a wide range of objectives and structures for alliancing. Nevertheless, there are certain concepts that will be common among most alliancing agreements. Some of these common elements are discussed in general terms below, with an emphasis on contractual-type relationships as opposed to partnerships and joint venture corporations.

\section{a. Background}

To set the context for the agreement, it is important to include relevant background facts that help to explain the nature of the relationship created by the agreement. For example, the parties should consider including background facts that underline the intention to create a cooperative relationship that is based on trust and good faith. The fact that the success of the alliance is dependent in large part on a cooperative spirit should be highlighted. The principles that distinguish alliances from other forms of business relationships should be embraced within the background facts.

\section{b. Information Exchange}

The parties may choose to describe the types of information that will be exchanged between the parties for the purpose of carrying out the agreement. The agreement should describe how both non-confidential and confidential information will be exchanged and managed. For example, the agreement may restrict access to certain types of information to select individuals. In addition, the agreement might describe the format for information transfer including the number of copies of written material, written or express identification of confidential information, and the return of information. The agreement may also list exceptions to the confidentiality provisions where the information is publicly available, has been developed independently by one of the partners, or was received from a third party.

\section{c. Management}

The form of management, as discussed above, will be very dependent upon the type of alliance. In the case of a joint venture corporation, management responsibilities are largely independent from the parent corporations. Partnerships and contractual alliances, on the other hand, will require management input from the constituent companies. In 
the case of a partnership, management may be accomplished by creating a committee composed of individuals from each partner who collectively are responsible for making the business decisions of the partnership. The partnership agreement will contain formulas for decision-making such as majority or unanimous voting schemes. Provisions should also be included which establish how deadlocks in decision-making will be managed. Possible options include appointing an additional representative to the committee from each partner company for the specific purpose of negotiating the deadlock, or entering into alternative dispute resolution such as mediation or arbitration. Management of contractual alliances can be structured in a similar manner to partnerships but may be less formal. For example, a contractual alliance could be managed by project coordinators or team leaders selected from each of the partners. Project coordinators would be responsible for ensuring the effective implementation of the agreement.

\section{d. Scope of Work}

Joint venture and partnership agreements will set out the authorized activities of the corporation or partnership. The authorized activities will reflect the purpose of the agreement. Alliancing contracts will likely contain more specific details concerning the work to be conducted by the alliance including provisions concerning manufacturing, quality, scheduling, delivery, marketing, sales, training and pricing.

\section{e. Intellectual Property}

The alliancing agreement may include provisions which allocate ownership of inventions that flow from the alliance. In the case of a joint venture corporation ownership of inventions would be vested in the joint venture corporation. For partnerships and contractual alliances ownership of inventions would likely be shared between the partners.

\section{f. Capital Investments}

Partnerships and contractual alliances should provide for the input of capital investment by the partners. In addition, consideration of future capital requirements is important.

\section{g. Allocation of Profits and Losses}

Formulas for allocating net profits and losses should be incorporated into the alliancing agreement. The precise formula will likely be dependent upon percent ownership, share of capital or resource investment.

\section{h. Termination}

Since most alliances are project or goal oriented, they are often disbanded upon completion of the mission. Consequently, it is important to provide for termination of the alliance. Termination may occur by the expiration of a prescribed time period. In 
such cases, parties may have an option to renew the agreement upon expiration of the primary term. Alternatively, termination may be accomplished through the mutual consent of the partners or, where there is no mutual consent, parties may be granted the right to terminate the agreement without cause after a specified notice period. In order to give the relationship a fair chance and to provide each of the parties with some security, the parties may choose to prohibit termination during a prescribed initial startup period. Termination may also be accomplished where one party has defaulted, and the default has not been corrected within a specified period. As another option, termination may occur automatically upon the happening of certain events, for example, bankruptcy, sale of the resources which were the focus of the agreement or the achievement of the desired objective.

\section{F. Alliances in the Canadian Offshore Petroleum INDUSTRY - THE TERRA NOVA EXPERIENCE}

The following is an outline of the recent experiences of Petro-Canada in connection with its alliancing strategies for the Terra Nova Project. ${ }^{32}$

\section{BACKGROUND}

In designing the Terra Nova offshore petroleum project, Petro-Canada considered two basic strategies: (1) "business as usual," a standard approach involving several different companies responsible for various aspects of the project, working, in large part, independently and under the principal direction of the operator, or (2) an alliancing strategy where the various participants would form a working unit, making joint decisions and working cooperatively. The former approach would produce predictable results for both cost and scheduling, while the latter approach would provide an opportunity, but not a guarantee, of achieving significant cost and scheduling reductions.

When Petro-Canada considered the Terra Nova project there were past examples of both successful and failed attempts at using strategic alliances in the development of offshore petroleum reserves. The alliancing strategy had been both in and out of vogue in the industry. Petro-Canada was of the view that it was the success in the Andrew Field, operated by BP Petroleum in the North Sea, that brought the idea of alliances in the development of offshore petroleum reserves back to the forefront.

The principal reason for structuring alliances in offshore development appeared to be the need for both increased efficiency and cost reductions in order to compete with less costly production from conventional land-based reserves. For example, operators in the North Sea, in the face of competition from low cost production in the Middle East and the depletion of major reserves in the North Sea, found that marginal reserves (less than 150 million barrels) would not be viable without significantly reducing costs. Cost reduction was seen as crucial for the survival of development in the North Sea.

12 The authors wish to acknowledge the valuable insight provided to us by Mr. Jim Ferrier, Leader, Co-Ventures Business Offshore Development \& Operations, Petro-Canada. 
To address this concern, the "CRINE" initiative (Cost Reduction Initiative in the New Era) was developed for the purpose of finding strategies for reducing costs in the development of offshore petroleum resources in the North Sea. Developed by industry representatives in the United Kingdom approximately five years ago, the CRINE Initiative determined that significant cost savings could be realized by changing business practices which were inherently wasteful or inefficient such as lack of coordination between the various parties involved in the development, lack of standardized practices and specifications, and document duplication. Alliancing was a strategy that was seen to address many of these issues.

\section{The Key Elements of Success in a Strategic Alliance}

Petro-Canada recognized that there is "no magic formula for operating an alliance; the alliance must be customized to each and every project." In addition, it was recognized that the alliance does not guarantee success - it gives only an opportunity to produce a better result. In Petro-Canada's view there were two key elements to achieving a successful alliance: (1) alignment, and (2) behaviour. Parties who intend to enter into an alliance must be prepared to invest a significant amount of time in maximizing both alignment and behaviour. The time required to achieve the maximum result should not be underestimated.

\section{a. Alignment}

It is typical in the design of an offshore project for the project manager to enter into agreements with several different suppliers of goods and services including engineers, fabricators, installers and drillers. In order for the project to come in at, or under, budget and on schedule, all of these individual entities must be coordinated. If any one of the entities is not in alignment, then the costs of any or all of the other parties may increase. For example, if the price estimated by a fabricator is dependent upon receiving the specific engineering data within a certain period of time, and the engineer fails to provide the information on schedule, then the fabricator's costs may increase accordingly. Where there is non-alignment, there are cost increases and schedule delays. A state of alignment is where each of the entities that form part of the project are coordinated and working as a unit. Alliances hope to achieve alignment.

\section{b. Behaviour}

In the case of behaviour, it is essential for the participants in the alliance to have behaviour characteristics such as trust and cooperation. Parties to an alliance must be able to work as a unit and must be able to resolve differences in an efficient manner. The difficulty in achieving such a result increases with the number of parties involved in the alliance.

\section{WHY AN ALLIANCE?}

Many of the classic reasons for entering into an alliance were present in Petro-Canada's reasoning for entering into an alliance concerning the Terra Nova 
project. One of the primary considerations was that Petro-Canada wanted to achieve a result that was better than "business as usual." It was anticipated that the alliance would enhance scheduling and reduce costs. In addition, the economics of the Terra Nova project were critical to its success; alliancing was seen as a means of competing with lower cost producers.

\section{SELECTION OF PARTNERS}

Petro-Canada's approach was based on achieving lower costs by having the alliance partners involved at the earliest planning stages possible. This was achieved by selecting several lead companies who were requested to put together a group of companies which could fulfil all of the various requirements of the project including engineering, procurement, construction and drilling. The three alliance groups which were invited to make submissions to Petro-Canada were: Alliance Newfoundland, Avalon Offshore Alliance and Grand Banks Alliance.

Petro-Canada imposed only one condition on the selection of companies to be involved in the project: each alliance group was required to include at least two Canadian companies where one of the two was based in Newfoundland. Petro-Canada recognized that the technical challenges posed by the Terra Nova project were beyond the scope of many Canadian companies; however, it was an important policy decision of Petro-Canada's to incorporate as much Canadian and local involvement as possible. In the end result, the successful alliance group, led by Brown \& Root, was the Grand Banks Alliance which included more than two Canadian companies.

Instead of establishing a traditional bid process, Petro-Canada required each of the alliance groups to participate in a design competition. The usual process for designing a project like Terra Nova would involve the project manager providing each of the participants with the applicable specifications for the project and identifying, in general terms, the type of design that was necessary. Each participant would then tender a bid for review by the project manager. In the case of the Terra Nova project, minimal design input was given from Petro-Canada. Petro-Canada's approach was to require each of the design groups to submit their suggested solution to the design problem.

Teams involved in the design competition were evaluated by Petro-Canada on both subjective and objective scales. The subjective assessment of each design group was based primarily on the group's ability to work together as a team; the ability to work cooperatively was seen as key to the success of the alliance. The remaining considerations were based on an evaluation of the groups' technical capabilities and their ability to achieve the target price and scheduling. The ability to achieve the target price and scheduling was evaluated by conducting a risk assessment of the estimated targets. The risk assessment included a statistic analysis of the parameter used to estimate the targets and resulted in an estimated probability of achieving the stated targets.

To facilitate the subjective assessment of each team, one representative from Petro-Canada worked with each of the design groups to act as a liaison between the 
design group and Petro-Canada. In addition, representatives of Petro-Canada (the Travel Team) attended regular meetings with each of the groups allowing for the free and candid exchange of questions, comments and ideas. Petro-Canada, where requested by the group, would give input concerning the project as the design competition proceeded.

The benefits of this process were primarily related to Petro-Canada's ability to observe how the groups worked together as an alliance, how they handled disagreements and how they dealt with technical difficulties. Ultimately, one group was found to have the best opportunity to give a "breakthrough result"; that is, the best chance of meeting the targeted cost estimates and project schedules.

\section{SHARING OF RISKS AND REWARDS}

The alliance that was ultimately selected for the Terra Nova project agreed to enter into a risk and reward program. In fact, each of the design groups were asked to include a proposal for the sharing of risks and rewards. Each of the risk and reward programs were similar in character; what typically differed was the magnitude of risk that the alliance was willing to share.

The sharing of risk between the members of the alliance was a new and challenging concept for many of the partners. Facing the reality that each member of the alliance would share in risks over which it may have no control was difficult. In response, the ability of each member of the alliance to provide its advertised result was scrutinized by the other members of the alliance. Since each partner had an interest in each other's success, there was greater incentive to work as a group.

The Grand Banks Alliance proposed a risk and reward program that included the sharing of both the risks and the benefits associated from going over and under the target price. The risks and rewards would be shared between the companies forming the alliance and Petro-Canada. In addition, the companies within the alliance would share risks and rewards based on an internal formula agreed to by the members of the alliance group. If the project came in under the target price, then both Petro-Canada and the alliance would share the benefits equally. If the actual cost exceeded the target price, then the alliance and Petro-Canada would share the loss up to a certain maximum dollar value.

\section{THE CONTRACTS}

The number of agreements and volume of contractual obligations for an alliance are normally much less than would be expected for the typical business relationship. Much more of the relationship in alliancing is based on trust. In Petro-Canada's view, an adversarial, traditional contract would be inconsistent with an alliance approach. If an adversarial relationship was entered into at the outset, there was a much greater chance that a confrontational tone would prevail if difficulties between the parties arose. It was thought that the parties would look to the contract to determine their rights as opposed to relying on the relationship to resolve differences. Petro-Canada hoped to structure the alliance relationship such that the parties would look to each other for solutions to 
difficult issues as opposed to the contracts. It was felt that, in a properly structured alliance, one should never have to rely or fall back upon the contractual obligations.

It was recognized that some agreements would be necessary in order to provide a basic framework to the alliance. Petro-Canada's approach was to first negotiate an interim agreement setting out the objectives and intentions of the alliance and informally addressing issues such as management, information exchange and confidentiality. This initial, informal process took approximately two months to complete. Some of the more challenging issues to resolve were based on the fact that the alliance involved six different companies, from different parts of the globe, each with different philosophies, cultures and management approaches. These differences needed to be addressed before a final agreement could be achieved.

After negotiating the interim agreement, the parties initiated the process of developing a formal alliancing agreement which captured the essential elements of the interim agreement. This process, which at the time of writing had involved four months of negotiating and drafting, was expected to be completed by the end of June 1997. Petro-Canada expects the final agreement to be much smaller in volume and complexity as compared to the traditional, contractual approach.

\section{MANAGEMENT}

Management of the alliance was achieved by structuring two primary alliance groups: (1) the Terra Nova Alliance Board (the Alliance Board); and (2) the Leadership Team. The Alliance Board is composed of senior members of management from each of the companies forming the alliance, including Petro-Canada, and is responsible for administering the alliance agreement. As such, the Alliance Board ensures that the project proceeds in accordance with the terms and intent of the formal alliance agreement. The Leadership Team is also composed of representatives of each of the alliance partners, but is chaired by Petro-Canada. The Leadership Team is responsible for implementing the alliance agreement and must report on a monthly basis to the Alliance Board. Monthly reports must include updates on the progress of the project. The Leadership Team must also provide a monthly progress report to an owner's management committee.

\section{LAWYERS AND ALLIANCES}

Legal counsel for the Terra Nova project were chosen in a separate process that was also based, in part, on principles of alliancing. The role of legal counsel was to include drafting royalty agreements, drafting the development and operating agreement which set out the arrangement between the owners and the operator for developing the project, and drafting the alliancing agreements. In Petro-Canada's experience, legal costs have been a significant factor in determining the final economics of the project (e.g. the Hibernia project). It was clear that in order to achieve the desired "breakthrough result," the cost reduction and risk and rewards strategies used in forming the alliance would have to apply in a similar manner to legal counsel. 
The law firms that were bidding on the Terra Nova project were asked to consider new ways to decrease costs associated with providing legal services and to propose strategies for sharing risks and rewards. Legal counsel were asked to consider concepts such as setting targets and performance objectives instead of the standard fee for service approach. The law firm that was ultimately selected set remuneration based on targeted person-hours and formulas that provided for the scaling of fees.

\section{THE RESULT}

The Terra Nova project is still in its infancy. Whether or not the alliancing strategy will achieve a "breakthrough result" has yet to be determined. In three years' time, the answer should be clearer. To date, Petro-Canada reports that the alliancing process has been largely a success in that target schedules have been achieved.

The lesson from Petro-Canada's perspective has been that successful alliancing essentially boils down to the fact that it is an all-win or all-lose proposition. In essence, the alliance is only as strong as its weakest link. Petro-Canada is of the view that if a company wants certainty then it should not select the alliance process. An alliance should only be chosen if the company is willing to take the risk of obtaining the possibility of significant cost reduction. The maximum benefit to be achieved by the alliance is a faster, cheaper and greater quality result.

\section{LABOUR Relations At Hibernia}

The construction phase of the Hibernia project is nearing completion and in preparation for production, the provincial government is considering all appropriate labour relations processes to ensure a harmonious labour relations climate on offshore production platforms that will optimize labour stability, health and safety and productivity. ${ }^{33}$

Late in 1996, the province of Newfoundland resolved to explore how labour relations on the Hibernia production platform could best be governed. Morgan Cooper, Assistant Professor of Industrial Relations at Memorial University, was named as the consultant to seek input from interested parties and make a report and recommendations to the Minister of Environment and Labour as to the most appropriate process for managing labour relations not only at Hibernia but as well at other production facilities in the Newfoundland offshore area. In this way the very special, perhaps unique, circumstances at Hibernia may well set the employment approaches for all future Newfoundland offshore oil and gas developments.

\section{A. Constitutional Background}

Only through the active agreement of the federal government does Newfoundland have any legislative jurisdiction over labour matters in the offshore area. As the Supreme Court of Canada stated in the Hibernia Reference: 
We therefore conclude that Newfoundland could not, upon its entry into Confederation, have held rights to explore and exploit the continental shelf by virtue of international law, because international law then conferred no such rights. Nor was it in any position to acquire such rights subsequent to Confederation.

The conclusion that Canada has the right to explore and exploit the Continental Shelf leads easily to the conclusion that Canada has legislative jurisdiction. ${ }^{34}$

As the continental shelf is beyond the territorial boundaries of Canada, ${ }^{35}$ no law will apply there unless it is expressly so extended. Section 8 of the CanadaNewfoundland Atlantic Accord Implementation Act ${ }^{36}$ provides that this Act applies in the offshore area. The offshore area includes the location of the Hibernia development.

By s. 152 of the Atlantic Accord Implementation Act, the application of certain provincial legislation, including Newfoundland's Labour Relations $A c t,{ }^{37}$ was extended to marine installations and structures within the offshore area in connection with petroleum exploration and production.

The constitutional validity of the equivalent provision in Nova Scotia's accord implementation legislation (The Canada-Nova Scotia Offshore Petroleum Resources Accord Implementation $\mathrm{Act}^{38}$ ) was upheld as an appropriate inter-delegation in Seafarers' International Union of Canada v. Canada (Labour Relations Board) ${ }^{39}$ in which the Federal Court of Canada stated "[t]here is no doubt that the anticipatory incorporation by reference of provincial legislation under subs. (2) and (4) of s. 157 of the Act is constitutionally valid." ${ }^{.0}$

By the operation of S. 152(4) of the Atlantic Accord Implementation Act, Newfoundland's Labour Relations Act applies on production platforms and other marine installations that are permanently attached to, anchored to or resting on the seabed of the offshore area. In the $S I U$ v. Rowan case, the production platform in question was a jack-up rig modified to include production facilities for the approximately ten-year Cohasset-Panuke oil production in the Nova Scotia offshore. It was considered by the Canada Labour Relations Board to be permanently attached to the seafloor. Hibernia's gravity-based structure with top sides attached is far beyond the Rowan Gorilla on the permanence index. Even Terra Nova's floating monohull production platform and semisubmersible drilling platform will probably be sufficiently anchored to the seafloor so that the provincial Labour Relations Act will apply instead of the federal Canada Labour Code. ${ }^{41}$

Re Seabead and Subsoil of Continental Shelf Ofshore Newfoundland, [1984] 1 S.C.R. 86 at 127. lbid. at 97.

S.C. 1987, c. 3 [hereinafter Allantic Accord Implementation Act].

R.S.N. 1990, c. L-1 [hereinafter Labour Relations $A c t$ ].

S.C. 1988, c. 28 [hereinafter Nova Scotia Implementation ACt].

(1993), 154 N.R. 314 [hereinafter SIU v. Rowan].

lbid. at 315.

R.S.C. 1985 , c. L-2. 
For these reasons, the Hibernia production platform will be governed by the same provincial trade union legislation which governed the construction of the gravity-based structure at Bull Arm: the Labour Relations Act.

\section{B. Labour Relations During the Construction Phase}

The construction site for Hibernia's gravity-based structure is located at Bull Arm, Trinity Bay, and in September of 1990 the Lieutenant Governor in Council designated that site as a "special project," as defined in s. 2(1)(u) of the Labour Relations Act as follows:

(u) "special project" means an undertaking for the construction of works designed to develop a natural resource or establish a primary industry that is planned to require a construction period exceeding 3 years, and includes all ancillary work, services and catering within a prescribed geographic site relating to the undertaking or project. ${ }^{42}$

The Lieutenant Governor in Council's order went on to provide that the party to any collective agreement on the contractor's side would be the Hibernia Employers' Association Inc. (HEA) and that the party on the employee's side would be the Newfoundland and Labrador Oil Development Allied Trades Council (ODC).

The construction industry is heavily unionized anyway, but the effect of the special project designation is to make the entire construction phase 100 percent unionized, with one union and one management for the purpose of collective bargaining.

Wells J. of the Newfoundland Supreme Court commented on the effect of the special project designation by Order-in-Council in the case of Re Labrador Relations Board (Nfld.) and Hibernia:

The Order-in-Council thus established a formula or system whereby the principal contractors and all subcontractors at the site were to be represented by HEA, and all affiliated unions which represented employees as defined, were to be represented by ODC. By implication it follows that the special project, once declared in the manner that it was, permits no other labour relations regime other than that specified by the Act and the Orders-in-Council. ${ }^{43}$

The jurisdiction of the Labour Relations Board is therefore entirely ousted by a special project designation.

In 1991, by further Order-in-Council, the Bull Arm site was expanded to include the resting place of the Hibernia platform at the production location; the order, however, still covered only the construction phase. ${ }^{44}$

$42 \quad$ Supra note 37. See Nfld. Reg. 223/90 (O.C. 667/90).

$4 \quad$ (1994), 119 Nfld. \& P.E.I.R. 311 (Nfld. S.C.) at 316-17.

$4 \quad$ Nfld. Reg. $79 / 91$ (O.C. 216/91). See M.C. Cooper, Labour Relations Processes on Offshore Oil Production Platforms (St. John's, Newfoundland, 25 April 1997) [unpublished] at 4 [hereinafter Morgan Cooper Report]. 
As the construction phase winds down towards completion, the parties and the government have been trying to work out how best to manage labour relations in the long term production phase. Hence the Morgan Cooper inquiry and report, which was released on 21 May 1997.

\section{THE MORgan COOPER Report}

Morgan Cooper's 85 page report is an excellent and thorough example of the synthesis of many different viewpoints, careful analysis of the real issues and wellbalanced recommendations. Highlights of the report are as follows:

\section{EMPLOYER AND EMPLOYEE CONCERNS}

Cooper identified the chief concerns of the employers, as submitted during the input phase of his inquiry:

(1) Certification and bargaining unit determination will cause undue fragmentation of the Hibernia production workforce, creating instability and causing a negative impact on productivity. Employers advocated a certification freeze until the production workforce is stabilized.

(2) Forcing employees to be represented by a council of trade unions may not be conducive to long-term employment harmony.

(3) Strikes and lockouts occurring over 300 kilometres from shore would be dangerous and financially disastrous.

Labour's concerns were these:

(1) Some wanted the special project designation to be expanded to include Hibernia's production phase.

(2) Some were willing to give up the right to strike only if the special project designation were so expanded. The alternative to the right to strike would be compulsory (or "interest") arbitration.

(3) If there were no special project designation, then the unions want to be assured of greater access to employees on the offshore platforms.

\section{No Special Project Designation}

Cooper notes that the special project status is traditionally reserved in Canada to the construction phase of mega-projects - due largely to the fragmented nature of the construction workforce. Specialized subcontractors participate in a project at differing times engaging in differing kinds of work. When they are done they move on. 
Cooper found no examples of special project status confirmed in respect of Canadian production (as opposed to construction) activities and concluded:

it would be very presumptuous to designate work on an offshore oil production platform as a "union" [or special] project without some indication of the level of support for unionization among the workforce.

In the Consultant's view, the employees who make up the workforce must be the ultimate judge of their interests on the issue of unionization as well as choice of bargaining agent. ${ }^{45}$

\section{THE APPROPRIATE BARGAINING UNIT}

Cooper noted the fairly clear consensus between management and labour that employees on each production platform should constitute a single bargaining unit, and he agreed with this position. Advantages to a single bargaining unit for each platform include lateral mobility for employees and the reduced risk of strikes.

The major disadvantage is the negative impact a platform-wide bargaining unit may have on the establishment of collective bargaining for offshore employees. There is comparatively limited collective bargaining, for instance, in the North Sea despite concerted organizing activity.

Cooper concluded that a change to the Labour Relations Act requiring single bargaining units for offshore production platforms without further flexibility would be a "crude substitute" for the discretion of the Labour Relations Board. He discussed the kind of flexibility the Labour Relations Board should retain in the next section of his report on the timing of certification applications.

\section{No FREeze on CERTIFICATION APPLICATIONS}

Industry representatives advocated a freeze on certification applications until employment on a platform stabilizes. Cooper recognized the "build-up principle" which has allowed labour relations boards to dismiss certification applications where the workforce is likely to rise significantly in the near future. He extended the same principle to the "build-down" phase where construction and testing employees were likely to leave the project after completing their short-term work to the production and maintenance teams. His reasoning continued as follows:

The discretion vested in labour relations boards to receive and rule on "build-up" or "build-down" arguments weakens the position of stakeholders advocating the imposition of a statutory freeze period. 
Although the Labour Relations Board's discretion to apply the build-up or build-down principle is one mechanism to balance the interests of present and future employees, there is also considerable merit in the request by Husky Oil for a statutory provision distinguishing construction and commissioning from production. If the supplementary workforce, consisting primarily of construction and commissioning employees, is separated from the core workforce for the purposes of bargaining unit determination, then the core workforce will be able to determine whether or not they wish union representation independent of the potentially divergent wishes of the supplementary workforce. ${ }^{46}$

He provided the following draft legislation to deal both with the scope of an offshore bargaining unit and the importance of dealing with a "steady state" workforce:

(1) Upon receipt of an application for certification in respect of employees on offshore oil and gas production platforms, the Board shall determine and order that the unit appropriate for collective bargaining is the unit comprised of all employees on an offshore oil and gas production platform with the exception of construction and start-up personnel, subject only to the exclusion of such positions as the Board may determine would otherwise normally be excluded.

(2) Upon receipt of an application for certification in respect of employees on offshore oil and gas platforms other than employees falling within the scope of subsection (1), the Board shall determine whether the unit in respect of which the application is made is appropriate for collective bargaining and the board may, before certification, where it considers it appropriate to do so, include additional employees in, or exclude employees from, the unit, and shall take those steps that it considers desirable to determine the wishes of the employees in the unit as to the selection of a bargaining agent to act on their behalf. ${ }^{47}$

\section{OPERATOR SHOULD LEAD EMPLOYER-SIDE REPRESENTATION}

Following the recommendation that the employees on each platform should form a single bargaining unit, the Morgan Cooper Report focuses on who should represent the various employers in the collective bargaining process.

Hibernia Management Development Corporation, Petro-Canada and Husky Oil (the operators of Hibernia, Terra Nova and White Rose, respectively), all advocated that the operator should represent the employers. The Newfoundland and Labrador Employers' Council favoured a more formal "accreditation" process. Cooper concluded:

Although it may be viable to simply designate the licensed production operator as the exclusive representative for all employers of employees in the platform-wide unit, the direct involvement of contractors in the hiring of personnel and the day-to-day supervision of the workforce strongly favours the creation of an employers' organization. The interests of licensed production operators and their contractors may be accommodated through an amendment to the Labour Relations Act requiring the Labour Relations Board, in response to an application for certification in relation to a platform-wide bargaining unit, to direct the licensed production operator to form an organization of all employers of 
employees in the unit vested with the appropriate authority to act as the exclusive bargaining agent for all employers of employees in the unit. ${ }^{48}$

It is submitted that if the Newfoundland government does amend the Labour Relations Act accordingly, offshore interest holders will be well advised to examine their joint operating agreements. They will probably have to be amended to take into account the shared responsibility of joint bargaining. Industry representatives may also wish to question the Labour Relations Board's requirement in the sample legislation for the operator to form an organization of all employers of platform workers. It is suggested that the composition of the employer "team" should be proposed by the operator subject to Labour Relations Board approval.

\title{
6. Labour RELATIONS BoARD to DETERMINE EMPLOYEE REPRESENTATIVES
}

As to which union or unions or council of unions should represent the employees in a bargaining unit (i.e. on a production platform), Cooper concluded that the Labour Relations Board should decide:

\begin{abstract}
A review of the principles espoused by the British Columbia and Canada Labour Relations Boards in addressing applications by councils of trade unions for certification in the context of bargaining unit consolidations, strongly suggests that the industry's concerns about workplace innovation, productivity, flexibility and competitiveness may be addressed by vesting the Labour Relations Board with discretion to determine the appropriateness of a council of trade unions as the bargaining agent for employees on offshore oil production platforms. ${ }^{49}$
\end{abstract}

\section{INCREASED UNION ACCESS to PLATFORMS}

Cooper has balanced the imposition of platform-wide bargaining units by recommending greater access by unions to offshore workers. It is a theme permeating the entire report that the Labour Relations Board's discretion is often preferable to fixed rules of legislation. He concludes:

[C]oncerns that the imposition of platform-wide bargaining units may be made at the expense of the ability to engage in collective bargaining may be lessened if the Board, in the exercise of its discretion, was required to provide "reasonable" and "economical" access to designated representatives of trade unions actively engaged in the organization of workers on offshore oil production platforms. The adoption of such a provision would ensure that trade union representatives are provided with an opportunity to interact with workers in their working environment. ${ }^{50}$

\section{MODIFIED RIGHT TO STRIKE OR LOCKOUT}

After a lengthy consideration of Canada's international obligations covering the freedom to associate and protection of the right to organize, and a well-balanced 
discussion of the importance of strikes and lockouts to achieve better collective agreements on the one hand and the danger to people, property and the environment of work stoppages on the other, Cooper concluded as follows:

(1) Strikes and lockouts should be barred only for the initial term of initial collective agreements. These terms should not be less than three years. For these initial agreements compulsory arbitration will settle otherwise unresolvable disputes.

(2) After the first agreement has expired, work stoppage rights should be available but should be exercised only in accordance with mutually agreed safety plans for orderly shutdown, which plans will include the designation of essential personnel and services to continue to work. ${ }^{51}$

\section{IMPLEMENTING THE MORGAN COOPER REPORT}

The government of Newfoundland and Labrador has indicated that it intends to implement the recommendations of the Morgan Cooper Report. This presents some interesting possibilities. Chiefly, what will happen if one union applies to represent one group of offshore workers before any new legislation is in force? Those interested will have to stay tuned.

\section{The Sable Gas Projects Joint Public Review Panel}

The project to produce gas from the Sable Island area (about 120 miles off the coast of Nova Scotia) and to transmit it to Boston is divided into two Canadian segments and one U.S. segment.

\section{A. Sable Offshore Energy Project (SOEP)}

The SOEP covers six gas fields in the vicinity of Sable Island. The six fields, the significant discovery licenses covering them, the owners of each field and their percentage ownership are shown in Schedule " $\mathrm{A}$ " attached to this article.

Gas from the six fields will be collected at Thebaud, where the central production and dehydration facilities will be located. The gas will then be transmitted via a 24-inch undersea pipeline to Country Harbour, Nova Scotia, about 225 kilometres from the production site.

While generally referred to as the "offshore" segment of the development, the SOEP includes the gas plant in Country Harbour, the natural gas liquids pipeline from the gas plant to Point Tupper, Nova Scotia and the natural gas liquids handling facility at Point Tupper. 


\section{B. Maritimes \& Northeast Pipeline Project (Mainline Project)}

The Mainline Project consists primarily of a 30-inch pipeline starting at the tailgate of the Country Harbour gas plant and ending 558 kilometres later at the U.S.-Canada border near St. Stephen, New Brunswick. It will connect at the border with a 24-inch pipeline carrying the gas to the Boston market.

The main transmission line has been recently redesigned to allow the reverse flow of gas from Boston towards and into New Brunswick and Nova Scotia.

\section{THE U.S. Segment}

The U.S. segment involves the construction of a pipeline from the Maine-New Brunswick border to Dracutt, Massachusetts. This segment is beyond the scope of this article.

\section{The Sable gas Projects Joint Public Review Panel}

The Sable Gas Projects Joint Public Review Panel was established last year to conduct all the public inquiries necessary under all federal and provincial legislation to allow the following government actions to be determined.

\section{SOEP APPROVALS}

\section{a. Development Plan}

The approval of the development plan application for the production of natural gas from the six gas fields and its transmission to Country Harbour, as required under s. 143(3) of the Nova Scotia Implementation Act. ${ }^{52}$ The Canada-Nova Scotia Offshore Petroleum Board (the CNSOPB) has jurisdiction only in the "offshore area" and consequently has no statutory interest in the gas plant or the natural gas liquids facilities. The development plan is a detailed and comprehensive document covering proposed production methods, health and safety plans, reservoir conservation, market studies and details, and environmental issues.

\section{b. Benefits Plan}

The approval, again by the CNSOPB, of the SOEP's Canada-Nova Scotia Benefits Plan is required under s. 45 of the Nova Scotia Implementation Act. ${ }^{53}$ The Benefits Plan sets out the proponents' intended efforts to hire locally and to use local suppliers. 


\section{c. Certificate of Public Convenience and Necessity}

A Certificate of Public Convenience and Necessity pursuant to s. 52 of the National Energy Board $\mathrm{Act}^{54}$ must be issued to the SOEP authorizing the construction and operation of the offshore pipelines connecting the six fields, the main pipeline carrying gas and gas liquids to Country Harbour, Nova Scotia, the gas plant at Country Harbour, the gas liquids pipeline from Country Harbour to Point Tupper, Nova Scotia and the gas liquids facilities at Point Tupper.

\section{d. Tolls and Tariffs}

An order respecting tolls and tariffs applicable to the SOEP pipelines is required pursuant to Part IV of the NEB Act. The SOEP proponents have requested that since they are the owners of both the pipelines and the gas, no tolls should be charged with respect to the pipelines connecting the six gas fields, the main subsea pipeline and the natural gas liquids pipeline to Point Tupper.

e. Permit to Construct

A permit to construct the SOEP's onshore natural gas liquids pipeline is required under s. 8 of the Pipeline $A c t,{ }^{55}$ and a licence to operate it under s. 12 of the same Act.

\section{f. Nova Scotia Environmental Approval}

Environmental assessment approval of the natural gas liquids pipeline and the gas plant may be needed under s. 40 of the Environment Act. ${ }^{56}$

g. Canadian Environmental Approval

Environmental assessment approval is required under the Canadian Environmental Assessment $\mathrm{Act}^{57}$ of:

(1) the offshore production facilities and the offshore pipelines (ss. 11 and 14 of the Comprehensive Study List Regulations ${ }^{58}$; and

(2) the gas plant and perhaps the natural gas liquids pipeline ss. 5(2) and s. 59(g) of the CEAA and s. 3 of the Law List Regulations. ${ }^{59}$

R.S.C. 1985 , c. N-7 [hereinafter $N E B A c t$ ].

R.S.N.S. 1989, c. 345.

S.N.S. 1994-95, c. 1.

S.C. 1992, c. 47 [hereinafter CEAA].

SOR/94-638. Enacted pursuant to s. 59(d) of the CEAA, ibid.

SOR/94-636. 


\section{Mainline Project}

a. Certificate of Public Convenience and Necessity

A Certificate of Public Convenience and Necessity must be issued to Maritimes \& Northeast Pipeline Limited (M\&NE) authorizing the construction and operation of the main transmission line from Country Harbour, Nova Scotia to the U.S. border at St. Stephen, New Brunswick. (Note that no laterals are included in the Mainline Project application, although the tolls M\&NE has applied for include the rolled-in cost of some laterals.)

\section{b. Tolls and Tariffs}

An order respecting tolls and tariffs for the carriage of gas through the main transmission line is needed under Part IV of the NEB Act. M\&NE have asked the NEB component of the Joint Public Review Panel to approve a postage stamp rate of sixty cents per MMbtu delivered anywhere in Nova Scotia or New Brunswick.

\section{c. Permit to Construct}

Subject to jurisdictional consideration, a permit to construct and a license to operate the main transmission line in Nova Scotia is needed under ss. 8 and 12 of the Pipeline Act. $^{60}$

\section{d. Nova Scotia Environmental Approval}

Subject to jurisdictional consideration, environmental assessment approval of the main transmission line is needed under s. 40 of the Environment Act. $^{61}$

\section{e. Canadian Environmental Approval}

Environmental assessment under the $C E A A$ of the main transmission line is required pursuant to both the Comprehensive Study List Regulations and the Law List Regulations.

Missing from this list are the necessary approvals required under New Brunswick law. The province of New Brunswick declined to join in the Joint Public Review Agreement, which was executed in June and July of 1996 by:

- Sergio Marchi, Minister of the Environment (Canada)

- Anne McLellan, Minister of Natural Resources (Canada)

- F. Wayne Adams, Minister of the Environment (Nova Scotia)

- Eleanor Norrie, Minister of Natural Resources (Nova Scotia)

- R. Priddle, Chair of the National Energy Board 
- J.E. Dickey, Acting Chief Executive Officer of the CNSOPB.

At the time the Joint Public Review Agreement was announced, it was reported that the government of New Brunswick took the position that the environmental review by the Joint Public Review Panel would be sufficient for the purposes of New Brunswick and that the formal participation of New Brunswick in the Joint Public Panel Review Agreement could add only unnecessary complexity.

That position was modified somewhat when the province of New Brunswick made a preliminary motion before the Joint Public Review Panel asking that the panel ensure that the Mainline Project proponents comply with a host of provincial statutes, mostly environmental. In the course of the application, the province watered down its somewhat confusing request and the panel, noting that National Energy Board certificates were normally conditional on compliance with applicable provincial law, agreed to take into account evidence given by the proponents that they would comply with provincial statutes.

\section{E. Joint Public Review Agreement}

The Joint Public Review Panel (Panel) is responsible for collecting the evidence necessary for the statutorily mandated bodies to be able to give the approvals, permits, certificates and licences referred to above. The Panel will also prepare a report on the environmental effects of both the SOEP and the Mainline Project.

The Panel has five members:

(1) Robert Fournier, the Panel Chair, is a professor of oceanography at Dalhousie University and a temporary member of the National Energy Board.

(2) Anita Côté-Verhaf is a full-time member of the National Energy Board.

(3) Ken Vollman is a full time member and Vice Chair of the National Energy Board.

(4) John Sears is a retired professor of Business Administration at St. Francis Xavier University in Antigonish, Nova Scotia. Mr. Sears fills the additional role of Commissioner to the CNSOPB and will also report to the Nova Scotia Mineral and Resources Conservation Board, which is responsible for granting permits and licences under the Nova Scotia Pipeline Act. $^{62}$

(5) Jessie Davies is Director of the Environment and Sustainable Development Research Centre at the University of New Brunswick.

The first three wear two hats each. In addition to preparing the report on the environmental effects of the projects, these three also act as the National Energy Board 
and will determine whether to grant Certificates of Public Convenience and Necessity, and on what terms and conditions. As the National Energy Board, these three will also set the tolls and tariffs to be charged for transporting the gas through the Canadian side of the pipeline.

The fourth, Sears, wears three hats: Panel member, Commissioner under the Nova Scotia Implementation $\mathrm{Act}^{63}$ to report back to the CNSOPB on environmental and socio-economic aspects of the offshore components of the SOEP, and advisor to the Energy and Mineral Resources Conservation Board under the Pipeline Act. ${ }^{64}$

Davies wears only the Panel hat. She would likely have played a role much like Sears' role in advising with respect to provincial legislation in New Brunswick, if the government of New Brunswick had chosen to pursue a route parallel to that of Nova Scotia.

The main focus of the Panel under the Joint Public Review Agreement is to review the environmental effects of the SOEP and Mainline Projects. Attached to the agreement is a list of factors to be considered by the Panel, including:

4. Alternatives to the Projects,

5. Alternative means of carrying out the Projects that are technologically and economically feasible and the Environmental Effects of any such alternative means,

10. The socio-economic effects of the Projects.... ${ }^{65}$

\section{F. Jurisdictional Issues Concerning the Panel}

A number of interesting jurisdictional issues concerning the Panel have already arisen.

\section{THE QUEBeC ROUTE}

Trans Quebec \& Maritimes Pipeline (TQM), jointly owned by Gaz Métropolitain Inc. and TransCanada Pipelines Ltd., asked the Panel to do one of the following:

(1) postpone the Mainline Project side of the hearings until after TQM has filed its application to carry Sable gas into Quebec instead of directly into the United States; or

is Item 2.I of Schedule 1, Agreement for a Joint Public Review of the Proposed Sable Gas Projects. Reprinted in NEB et al., The Joint Public Review Panel Report - Sable Gas Projects (October 1997) at 120. 
(2) let the hearings proceed on both projects but postpone any decision until after the Panel has heard TQM's additional information in August and September.

TQM's argument was that the Panel has a duty to consider alternatives to the Mainline Project and alternative means to the method of implementing the Mainline Project as these factors were included in the list of factors attached to the Joint Public Review Agreement (cited above). In its submission, TQM stated that "the tying in of Sable gas reserves to the trans-Canadian gas transportation system on economically feasible terms is among the most important issues...." ${ }^{66} \mathrm{TQM}$ also said that "giving the largest number of Canadians access to a Canadian natural resource is in the Canadian public interest." 67

TQM referred to the above submissions and stated "TQM ... believes that the foregoing issues must be considered by the Joint Review Panel and is participating in these proceedings under reserve of its rights in that regard."

It is submitted that this position is far too broad. It is clear from the Joint Public Review Agreement that the only purpose of the Panel under the agreement is to conduct a review of the environmental effects of the Sable gas projects. In this connection but, again it is submitted, only in this connection, are alternatives to the projects or alternative means to carry out the projects to be reviewed. TQM included in its submission a legal opinion on this subject from its counsel, the Lavery, de Billy law firm. The opinion was very careful to say nothing more than "we conclude that the TQM Project would constitute an alternative to the M\&NE Project the environmental effects of which must be reviewed by the Joint Review Panel."

TQM was not so narrow as its counsel and did not confine the Panel's duty to consider alternatives and alternative means to their environmental effects. In its submission, TQM refers to, among other things, broadening Canadian access to a Canadian natural resource, economic considerations underpinning the Projects, the interconnection of Sable gas resources to the Canadian transportation grid, and its Certificate of Public Convenience and Necessity Number GC-68. TQM says that the Panel must consider these "alternative" issues.

It is submitted that these issues cited by TQM are beyond the scope of the Panel's only "alternative" duty: to consider the environmental effects of alternatives and alternative means such as TQM's proposal to carry Sable gas to Quebec.

The Panel considered TQM's submissions in this regard prior to the commencement of the hearings. It decided not to delay the hearings, but to consider at their conclusion

Joint Public Review, Written Evidence/Preliminary Submission (7 March 1997), Tab A, at 2.

lbid.

Ibid. at 3 [emphasis added].

Ibid. at 7 .

Ibid. at 3. 
whether or not a review of TQM's full and separate application is necessary to fulfil its mandate to assess the environmental effects of the SOEP and Mainline Projects.

\section{THE INTERVENTION OF THE PRIME Minister}

The press reported that on 8 June 1996 Prime Minister Chrétien and Premier Bouchard agreed to support the TQM route for Sable gas.

These remarks may have been ill-advised, but one environmental group made the preliminary motion on the first day of the hearing that the independence of the Panel was compromised by Prime Minister Chrétien's stated preference to such a degree that the Panel ought to disband itself. The speaker for the environmental group cited this editorial comment from the Halifax Chronicle Herald: "what credibility does the NEB process have when Mr. Chrétien who has ultimate power to overrule the NEB, endorses TQM's distribution bid before it is even put forward?"71

After several hours of hearing time, the Panel had little difficultly in dismissing this application on the grounds that there was not a close enough connection between the Prime Minister's remarks and the individual Panel members so as to diminish the independence of their review of the facts and their ability to reach unbiased conclusions.

The spokesperson for the environmental group had recently announced his candidacy for the New Democratic Party in the then-upcoming federal elections. In the authors' view, to the extent that intervener funding was used to cover any part of the cost of the application, the application constituted an abuse of the privilege of intervener funding.

\section{The Provinces versus the National Energy BoARd In the Lateral ARENA}

This constitutional battle over laterals has not yet been joined, but it seems inevitable - especially in Nova Scotia.

As Ottawa and Nova Scotia have agreed to put aside jurisdictional questions in the offshore area in favour of joint management by the CNSOPB, Nova Scotia has not asserted any claim that its Pipeline Act applies in the offshore area.

The main onshore pipeline itself is an inter-provincial work and undertaking and therefore subject to exclusive federal jurisdiction. The Province does not challenge this.

The intriguing question is whether the laterals constructed to bring gas from the mainline to customers in Nova Scotia and New Brunswick will constitute federal works or undertakings themselves, or are so integral to a federal work or undertaking as to be subject to federal jurisdiction. The following factors may be relevant in the determination of the constitutionality of the laterals: 
(1) The Mainline Project application before the National Energy Board subpanel does not include any laterals although the main line will be built with side valves at points where laterals are likely to be required. Consequently, laterals may be built by M\&NE or by others.

(2) Each lateral contemplated so far will be wholly within the boundaries of one province.

(3) M\&NE has proposed a rate structure which includes rolled-in lateral construction costs. This rate structure would spread the cost of some laterals over all users in two provinces and would tend, through common ownership, toward the finding of federal jurisdiction.

(4) The evidence of M\&NE at the hearing is that no Canadian sales are required to support the construction of the mainline. The entire project can be justified economically on sales to the northeastern United States market. The intraprovincial laterals may then be seen as less than integral to the inter-provincial mainline.

\section{G. SUMMARY}

At the time of writing, the hearings have progressed quite smoothly despite their unusual composition and varied objectives, although they will extend a bit beyond their original schedule. Great care has been taken to obtain all the necessary information to allow the various decision-makers to perform their statutory duties once the information gathering by the Joint Review Panel has been completed. It will be particularly interesting to see how the Panel will deal with TQM's proposals to have its project evaluated as a necessary component of the SOEP and Mainline Project applications. 


\section{SCHEDULE A}

\section{Sable Offshore Energy Project}

INTEREST AND INTEREST OWNERS

\begin{tabular}{|c|c|c|c|c|c|c|c|c|c|c|c|c|c|}
\hline & & & \multicolumn{5}{|c|}{ SOEP INTEREST OWNERS } & \multicolumn{6}{|c|}{ OTHER INTERESTED OWNERS } \\
\hline FIELD & SDL & HECTARES & MOBIL & & SHELL & IMPERIAL & NSRV & CU GS & & FOREST & SPARTAN & TALISMAN & MOSBACHER \\
\hline Venture & 2254 & 10388 & $49.5000 \%$ & $22.5000 \%$ & $18.0000 \%$ & $10.0000 \%$ & & & & & & & \\
\hline \multirow[t]{2}{*}{ South Venture } & 2255A & 5565 & $49.5000 \%$ & $22.5000 \%$ & $18.0000 \%$ & $10.0000 \%$ & & & & & & & \\
\hline & 2255B & 742 & $49.5000 \%$ & $22.5000 \%$ & $12.32982 \%$ & $10.0000 \%$ & & $1.83509 \%$ & $2.83509 \%$ & & & & \\
\hline \multirow[t]{3}{*}{ Thebaud } & $2255 \mathrm{~F}$ & 1274 & $67.5000 \%$ & $22.5000 \%$ & $10.0000 \%$ & & & & & & & & \\
\hline & $2255 \mathrm{G}$ & 5050 & $67.5000 \%$ & $22.5000 \%$ & $10.0000 \%$ & & & & & & & & \\
\hline & $2283 \mathrm{C}$ & 372 & $67.5000 \%$ & $22.5000 \%$ & $10.0000 \%$ & & & & & & & & \\
\hline \multirow[t]{3}{*}{ North Triumph } & 2269 & 746 & $43.7500 \%$ & & & & & & & $12.5000 \%$ & $43.7500 \%$ & & \\
\hline & $2267 \mathrm{~B}$ & 5968 & $40.1250 \%$ & $52.3750 \%$ & & $7.5000 \%$ & & & & & & & \\
\hline & $2276 \mathrm{C}$ & 1119 & $33.8750 \%$ & $63.6250 \%$ & & $2.5000 \%$ & & & & & & & \\
\hline Gleneig & 2299A & 5968 & $40.9235 \%$ & $57.6765 \%$ & & $1.4000 \%$ & & & & & & & \\
\hline \multirow[t]{2}{*}{ Alma } & $2277 \mathrm{~A}$ & 8219 & $25.2750 \%$ & $68.1250 \%$ & & $2.0000 \%$ & & & & & & & $4.6000 \%$ \\
\hline & $2277 \mathrm{~B}$ & 374 & $30.9000 \%$ & $57.5000 \%$ & & $7.0000 \%$ & & & & & & & $4.6000 \%$ \\
\hline
\end{tabular}

